\title{
Tonga's Metaphoric Hangings
}

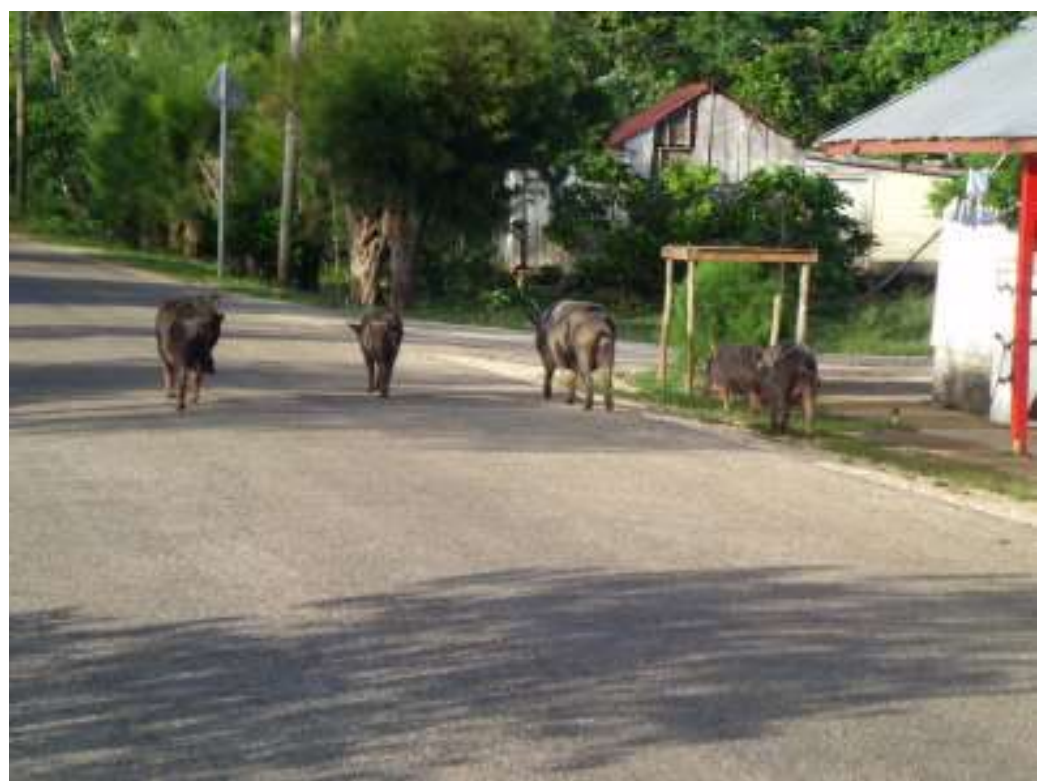

Photograph Credit: Teena Brown Pulu

In the small island developing state of Tonga, metaphoric hangings were going off at the top-level of national politics. Matangi Tonga Online was first to break the story in English. The tale unfolded that the former education secretary, 'Emeli Moala Pouvalu, was leading a petition to be submitted to King Tupou VI on October 21st. "A group including teachers and others had written a proposal" that formed part of the petition. They wanted Prime Minister, 'Akilisi Pohiva, fired as education minister. As well, they also called for the dismissal of the 
acting education minister in Pohiva's absence, 'Etuate Lavulavu.

'Emeli claimed that both ministers [Pohiva and Lavulavu] had abused their position with conflicts of interest, nepotism, and by breaking the laws and the regulation of the Ministry [of Education]. She said the petitioners had evidence to support their claims.

English language media was consistent in listing the allegations against Pohiva and Lavulavu. However, reporting discrepancy surfaced over who was the petition's driving force. Radio New Zealand begged to differ with Matangi Tonga Online, contending "the petition is not from a particular group" of teachers at all.

The former chief executive ['Emeli Moala Pouvalu] says the petition is not from a particular group, but from people who are interested in education, including parents.

Quibbling about the petition's authorship and political motivation aside, Pouvalu confessed to Matangi Tonga Online the actual issue at stake: "He [Pohiva] did not trust me and I did not trust him." This was compounded by the fact that education ministry staff "were scared of angering the Minister who would punish them."

The petition's driver was really breach of trust. There were senior bureaucrats in Tonga's public service who saw Prime Minister Pohiva and Minister Lavulavu had behaved in ways that could not be trusted. An absence of trust in relationships between Pohiva, his cabinet, and senior government officials, was a constant problem fashioning a dysfunctional Tongan bureaucracy.

It also produced a politically unstable environment where ministers following the Prime Minister's lead, went out on a 
limb to make offbeat media comments that did not appear to be consulted on within their ministries. A stand-out example was justice minister Vuna Fa'otusia's belief that the death penalty would remained fixed in Tongan law.

Ben Robinson for Radio New Zealand rehabilitated the subject of death penalty laws in Pacific Islands' countries for public debate. October 10th was the 13th United Nations World Day against the Death Penalty. Running a story on Tonga, Nauru, and Papua New Guinea who still had the death sentence in national legislation, he inquired whether these states leaned towards abolition in practice.

Tonga was the last Pacific Islands' state to have used the death penalty set-out in the Criminal Offences Act, Revised 1988. In 1982, three men were hung as capital punishment for a murder conviction in the village of Vaini. The President of Tonga's Law Society, Laki Niu, explained to Robinson if there was an inclination to eliminate the death penalty, then it was "the trial judges" who were reluctant "to sentence people to death."

Soon afterwards [in 1982] there were motions made to the government to abolish hanging. But the parliament didn't approve it. They didn't change the law, and it is the law up to now. Although, I must say there have been murders committed, serious ones as well, but it would appear that the trial judges since 1982 do not wish to sentence people to death.

The "trial judges" of the Supreme Court and Privy Council whom Niu referred to, particularly the line of Chief Justices appointed from 1982 to the present-day, were European not Tongan. To bluntly restate historical fact, "trial judges" employed outside of the Tongan district court at the upper tiers of Supreme Court, and Privy Council, were primarily white men not Tongan nationals by bloodlines or citizenship. 
Where did that leave Tongan tastes, canons, and political interests in respect of canning, or keeping, the death penalty in national legislation? Justice Minister Fa'otusia stepped in to speak his mind on the subject, and perhaps inadvertently, put his foot in his mouth.

Sometimes there are cases that definitely deserve the ultimate price, i.e. death penalty. I believe that is the view of the previous government, and also, our present government now. So, we don't expect to change it anytime sooner. We're comfortable just leaving it there in the law [rather than] repealing it altogether.

The Pohiva government is "comfortable leaving [the death sentence] there in law," avowed Fa'otusia. What was there to be snug about? Furthermore, why did the justice minister "believe" the former Tu'ivakano administration was relaxed about not abolishing capital punishment by hanging?

Fa'otusia was speaking off the cuff. For Tonga's justice minister to put his opinion across to media as the official policy of his government, and the former administration, was alarming seeing the story was framed by the United Nations World Day against the Death Penalty. Pohiva's regime showed no willingness to grasp the rationale propelling World Day against the Death Penalty in that sentencing people to death did not act a deterrent to criminal offences.

Fao'tusia's contentment to maintain the death penalty in law silenced any public disagreement. Coming from the Tongan government led by the Democratic Party of the Friendly Islands, how democratic in principle and practice was that? 